\title{
Effect of a New Aldose Reductase Inhibitor, (E)-3-Carboxymethyl-5-[(2E)-Methyl-3-Phenylpropenylidene]Rhodanine (ONO-2235) on Peripheral Nerve Disorders in Streptozotocin-Diabetic Rats
}

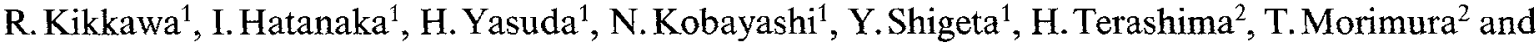 \\ M. Tsuboshima ${ }^{2}$ \\ ${ }^{1}$ Third Department of Medicine, Shiga University of Medical Science, Ohtsu City, Shiga and \\ ${ }^{2}$ Bio-Science Department, Research Institute, Ono Pharmaceuticals, Osaka, Japan
}

Summary. A new aldose reductase inhibitor, (E)-3-carboxymethyl-5-[(2E-methyl-3-phenylpropenylidene]rhodanine (ONO-2235) was administered orally to streptozotocin-diabetic rats $(60 \mathrm{mg} / \mathrm{kg} \mathrm{IV})$ for 14 days and its effect on motor nerve conduction velocity studied. The compound significantly improved motor nerve conduction velocity of diabetic rats at a minimal dose of $10 \mathrm{mg} \cdot \mathrm{kg}^{-1}$. day ${ }^{-1}$ (treated $28.8 \pm 0.5$ versus untreated $23.2 \pm 4.7 \mathrm{~m} / \mathrm{s}, p<0.01$ ). The sorbitol content of the sciatic nerve and red blood cells measured after 2 weeks was concomitantly reduced in ONO-2235-treated rats (sciatic nerve: $120 \pm 13$ versus $595 \pm 146 \mathrm{nmol} / \mathrm{g}$ wet weight; red blood cell: $91 \pm 21$ versus $165 \pm 39 \mathrm{nmol} / \mathrm{g}$ haemoglobin; $p<0.01$ in both $20 \mathrm{mg} \cdot \mathrm{kg}^{-1}$. day ${ }^{-1}$-treated versus untreated animals). These results suggest that sorbitol accumulation might contribute to the development of peripheral nerve dysfunction in acutely diabetic animals and the new aldose reductase inhibitor could be a potential drug for therapy of diabetic neuropathy.

Key words: Aldose reductase inhibitor, streptozotocin-diabetic rats, sciatic nerve sorbitol, red cell sorbitol.
There have been several reports that imply the importance of polyol accumulation in peripheral nerve tissue in the pathogenesis of diabetic neuropathy $[1,2]$. Furthermore, inhibitors of aldose reductase, a key enzyme for polyol synthesis, have been reported to improve the conduction abnormalities of peripheral nerves in animal experiments $[3,4]$ and clinical trials $[5,6]$. We have developed a new and potent aldose reductase inhibitor, a rhodanine derivative, and studied its effect on peripheral nerve abnormalities in streptozotocin-diabetic rats.

\section{Materials and Methods}

\section{Animals}

Male Sprague-Dawley rats weighing approximately $250 \mathrm{~g}$ and 8 weeks old were used for the experiment. Diabetes was induced by IV injection of streptozotocin $(60 \mathrm{mg} / \mathrm{kg}$ body weight) dissolved in citrate buffer ( $\mathrm{pH} 4.5)$. All rats were kept in identical cages and had free access to laboratory chow and water.

The following treatments were started 2 weeks after the induction of diabetes: (E)-3-carboxymethyl-5-[(2E)-methyl-3-phenylpropenylidene]rhodanine (ONO-2235), suspended in gum arabic, was given via gastric tubing at a daily dose of 10,20 or $40 \mathrm{mg} / \mathrm{kg}$ for 2 weeks. Ultralente insulin was injected SC at approximately $18.00 \mathrm{~h}$ daily for 2 weeks at doses varying between $6-18 \mathrm{U}$ according to the plasma glucose level.

\section{Analytical Methods}

Motor nerve conduction velocity (MNCV) was used as a sensitive and quantitative indicator of functional change in peripheral nerves [7, 8], although there has been dispute about its validity [9]. Weekly measurements of $\mathrm{MNCV}$ were performed according to the previously reported technique using the tail nerve [8]. At the end of the experiments both sciatic nerves were quickly removed by incision, weighed and homogenised in $8 \%(\mathrm{w} / \mathrm{v}) \mathrm{HClO}_{4}(0.5 \mathrm{ml})$ and centrifuged at $3000 \mathrm{rev} / \mathrm{min}$ for $10 \mathrm{~min}$. The supernatants were neutralised with $2 \mathrm{~N}$ $\mathrm{KOH}$ and their sorbitol content determined by the enzymatic method of Bergmeyer et al. [11]. At the same time blood samples were obtained and the erythrocyte sorbitol content measured according to the method of Malone et al. [12].

\section{Results}

The body weight of streptozotocin-diabetic rats was significantly reduced 2 weeks after streptozotocin injection compared with normal rats (diabetic rats: $233 \pm 23 \mathrm{~g}$, $n=33$, versus normal rats: $315 \pm 14 \mathrm{~g}, n=6, p<0.005$ ). Plasma glucose was also significantly increased in diabetic rats $(29.1 \pm 3.0 \mathrm{mmol} / 1, n=33$, versus $7.8 \pm$ $2.0 \mathrm{mmol} / 1, n=6$ for control rats, $p<0.005)$. The diabetic rats were divided randomly into three groups: ONO-2235-treated, insulin-treated and untreated. The administration of ONO-2235 had no effect on body weight or plasma glucose, but daily insulin injection 
Table 1. Motor nerve conduction velocity of streptozotocin-diabetic rats before and after treatment with ONO-2235 or insulin

\begin{tabular}{llll}
\hline Treatment & \multicolumn{3}{l}{ Motor nerve conduction velocity $(\mathrm{m} / \mathrm{s})$} \\
\cline { 2 - 4 } & Day 0 & Day 7 & Day 14 \\
\hline $\begin{array}{l}\text { Normal rats }(n=6) \\
\text { Diabetic rats }\end{array}$ & $34.1 \pm 0.9$ & $35.7 \pm 4.0$ & $38.8 \pm 7.4$ \\
$\quad$ Untreated rats $(n=5)$ & $24.4 \pm 1.7$ & $24.6 \pm 3.2$ & $23.2 \pm 4.7$ \\
ONO-treated rats & & & \\
$\quad 10 \mathrm{mg} / \mathrm{kg}(n=6)$ & $22.4 \pm 1.3$ & $25.4 \pm 2.0$ & $28.8 \pm 0.5^{\mathrm{a}}$ \\
$20 \mathrm{mg} / \mathrm{kg}(n=6)$ & $24.4 \pm 1.7$ & $32.7 \pm 3.1^{\mathrm{a}}$ & $30.7 \pm 3.2^{\mathrm{a}}$ \\
$\quad 40 \mathrm{mg} / \mathrm{kg}(n=7)$ & $22.7 \pm 2.7$ & $30.1 \pm 2.6^{\mathrm{a}}$ & $30.1 \pm 0.7^{\mathrm{a}}$ \\
Insulin-treated rats & $22.6 \pm 3.3$ & $32.8 \pm 1.5^{\mathrm{a}}$ & $30.1 \pm 3.2^{\mathrm{a}}$ \\
$(n=9)$ & & & \\
\hline
\end{tabular}

Results expressed as mean $\pm \mathrm{SD} ;{ }^{a} p<0.01$ versus untreated rats

Table 2. Sorbitol content of sciatic nerve and red blood cells of treated and untreated diabetic rats

\begin{tabular}{lcc}
\hline Treatment & \multicolumn{2}{l}{ Sorbitol content } \\
\cline { 2 - 3 } & $\begin{array}{l}\text { Sciatic nerve } \\
\text { (nmol/g wet } \\
\text { weight) }\end{array}$ & $\begin{array}{l}\text { Red blood cells } \\
\text { (nmol/g } \\
\text { haemoglobin) }\end{array}$ \\
\hline Normal rats $(n=6)$ & $44 \pm 9$ & $26 \pm 6$ \\
Diabetic rats & & \\
$\quad$ Untreated rats $(n=5)$ & $595 \pm 146$ & $165 \pm 39$ \\
ONO-2235-treated & $191 \pm 54^{\mathrm{a}}$ & $118 \pm 19$ \\
$\quad 10 \mathrm{mg} / \mathrm{kg}(n=5)$ & $120 \pm 13^{\mathrm{a}}$ & $91 \pm 21^{\mathrm{a}}$ \\
$20 \mathrm{mg} / \mathrm{kg}(n=3)$ & $125 \pm 33^{\mathrm{a}}$ & $108 \pm 8^{\mathrm{a}}$ \\
$\quad 40 \mathrm{mg} / \mathrm{kg}(n=6)$ & $66 \pm 13^{\mathrm{a}}$ & $19 \pm 8^{\mathrm{a}}$ \\
\hline Insulin-treated $(n=8)$ &
\end{tabular}

Results expressed as mean $\pm \mathrm{SD} ;{ }^{\mathrm{a}} p<0.01$ versus untreated rats

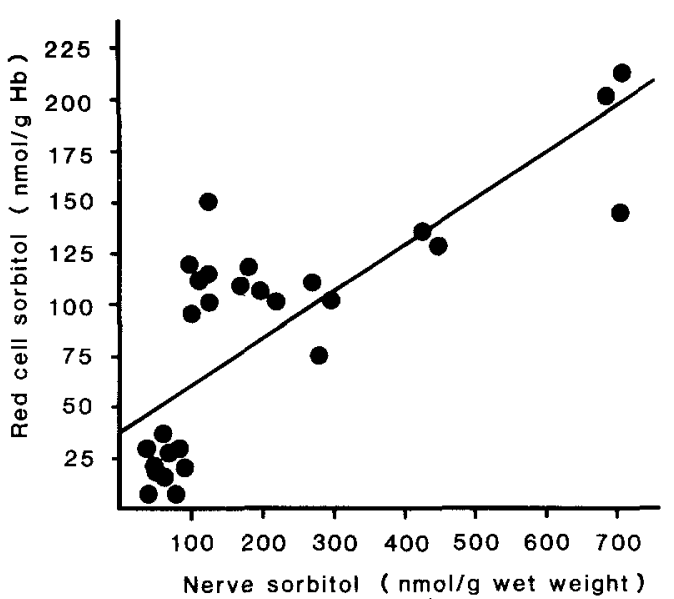

Fig. 1. Correlation of sorbitol content of sciatic nerve with that of red blood cells in all experimental rats. The values in individual rats are correlated $(r=0.78, p<0.01)$

caused a noticeable increase of body weight from $256 \pm 26$ to $330 \pm 57 \mathrm{~g}$ and a reduction of plasma glucose from $29.5 \pm 3.9$ to $5.1 \pm 2.2 \mathrm{mmol} / 1$.

MNCV was significantly reduced in the streptozotocin-diabetic rats $(23.2 \pm 2.3 \mathrm{~m} / \mathrm{s}, n=33$, versus normal rats $34.1 \pm 0.9 \mathrm{~m} / \mathrm{s}, n=6, p<0.005)$. As shown in Table 1, insulin resulted in a significant improvement of
MNCV after one week of treatment. In all groups treated with ONO-2235 $(10,20$ and $40 \mathrm{mg} / \mathrm{kg})$, MNCV was significantly improved compared with the untreated group on both days 7 and 14 except for the lowest dose at day 7 , which could reflect a dose-dependent effect of this compound on MNCV.

The sorbitol content of sciatic nerve and red blood cells was significantly increased in the untreated diabetic rats compared with the control rats (Table 2). Both insulin and ONO-2235 significantly reduced the sorbitol content of sciatic nerve. There appeared a dose-dependency in the reduction induced by ONO-2235, though no apparent difference between the reduction at 20 and $40 \mathrm{mg} / \mathrm{kg}$ suggests a limiting effect at these dosages.

Insulin treatment for 14 days completely normalized the red cell sorbitol, while ONO-2235 was surprisingly less effective. Although insulin was equally effective at reducing sorbitol levels in both sciatic nerve and red cells, ONO-2235 was relatively ineffectual in red cells, compared with its effect on sciatic nerve sorbitol levels.

To find out whether the sorbitol content of red cells reflected that of nerve tissue, the relationship between the two was analysed (Fig. 1). Sorbitol values of red cells from all experimental rats correlated significantly to those of sciatic nerve from the same individual rats $(r=0.79, p<0.005)$.

\section{Discussion}

ONO-2235 is a newly developed aldose reductase inhibitor and is structurally different from the previously reported inhibitors, alrestatin $[3,5]$ and sorbinil $[4,6]$. The potency of this new compound in inhibiting aldose reductase appears similar to that of sorbinil $[3,4]$ and $50-100$ times higher than alrestatin. It seems likely that ONO-2235 ameliorated peripheral nerve dysfunction of diabetic rats by reducing sorbitol accumulation in the nerve tissue, though the possibility that this compound might have effects on other metabolic pathways cannot be ruled out. In fact, several compounds appear to improve peripheral nerve function without reducing sorbitol accumulation or inhibiting aldose reductase in diabetic animals $[7,10,13]$.

The finding in this study that sorbitol levels of red cells significantly correlated with those of sciatic nerve, is in agreement with a previous observation by Malone et al. [12] and may be important clinically for the measurement of sorbitol. However, the percentage reduction of sorbitol was considerably less in red cells than in sciatic nerve at the same dosage, which could be due to a different transport rate of the compound ONO-2235 between red cells and nerve tissue. Alternatively, aldose reductase(s) and their susceptibilities to inhibitors may be different in the two tissues. Furthermore, biochemical properties of aldose reductases are not necessarily consistent in various species [14]. Therefore, it is important to study the properties of aldose reductase inhib- 
itors using various tissues and species, before using red cell sorbitol values to monitor nerve tissue content in clinical trials.

Acknowledgments. The authors wish to thank Miss H. Nozaki for excellent assistance during the experimental work.

\section{References}

1. Stewart MA, Sherman WR, Anthony S (1966) Free sugars in alloxan diabetic rat nerve. Biochem Biophys Res Commun 22:488-491

2. Gabbay KH (1973) The sorbitol pathway and the complications of diabetes. N Engl J Med 288: 831-836

3. Dvornik D, Simard-Duquesne N, Krami M, Sestanj K, Gabbay KH, Kinoshita JH, Varma SD, Merola O (1973) Polyol accumulation in galactosemic and diabetic rats: control by an aldose reductase inhibitor. Science 182: 1146-1148

4. Peterson MJ, Sarges R, Aldinger CE, MacDonald DP (1979) CP45,634: A novel aldose reductase inhibitor that inhibits polyol pathway activity in diabetic and galactosemic rats. Metabolism 28: $456-461$

5. Handelsman DJ, Turtle JR (1981) Clinical trial of an aldose reductase inhibitor in diabetic neuropathy. Diabetes 30: 459-464

6. Judzewitsch R, Jaspan JB, Pfeifer MA, Polonsky KS, Halar E, Vukadinovic C, Richton S, Gabbay K, Rubenstein AH, Porte DJr (1981) Inhibition of aldose reductase improves motor nerve conduction velocity in diabetics. Diabetes 30, Suppl 1: 118 (Abstract)

7. Greene DA, Lewis RA, Lattimer SA, Brown MJ (1982) Selective effects of myo-inositol administration on sciatic and tibial motor nerve conduction parameters in the streptozotocin-diabetic rat. Diabetes 31: $573-578$
8. Miyoshi T, Goto I (1973) Serial in vivo determinations of nerve conduction velocity in rat tails: physiological and pathological change. Electroencephalogr Clin Neurophysiol 35: 125-131

9. Thomas PK, Jefferys JGR, Sharma AK, Bajada S (1981) Nerve conduction velocity in experimental diabetes in the rat and rabbit. J Neurol Neurosurg Psychiatr 44: 233-238

10. Kikkawa R, Hatanaka I, Kobayashi N, Yasuda H, Shigeta Y (1982) The effect of aldose reductase inhibitor (sorbinil) and methylcobalamin on peripheral nerve disorders in streptozotocindiabetic rats. In: Goto Y, Horiuchi A, Kogure K (eds) Proceedings of the International Symposium on Diabetic Neuropathy and Its Treatment, Tokyo. Excepta Medica, Amsterdam, International Congress Series 581: 350-354

11. Bergmeyer HV, Gruber W, Gutamann I (1974) D-Sorbitol. In: Bergmeyer HV (ed) Methods of enzymatic analysis, Academic Press, New York, pp 1323-1326

12. Malone JI, Knox G, Benford S, Tedesco TA (1980) Red cell sorbitol. An indicator of diabetic control. Diabetes 29: 861-864

13. Greene DA, De Jesus PV, Winegrad AI (1975) Effects of insulin and dietary myoinositol on impaired peripheral motor nerve conduction velocity in acutely streptozotocin diabetes. J Clin Invest 55: 1326-1336

14. Kador HP, Kinoshita JH, Tung WH, Chylack LT (1980) Differences in the susceptibility of various aldose reductases to inhibition. Invest Ophthalmol Vis Soc 19: 980-982

Received: 19 April 1982

and in revised form: 15 December 1982

Dr. R. Kikkawa

Third Department of Medicine

Shiga University of Medical Science

Seta, Ohtsu, Shiga 520-21

Japan 